\title{
EFEK DIET ATEROGENIK TERHADAP GAMBARAN HISTOPATOLOGIS HATI MENCIT (Mus musculus) The Effect of Aterogenic Diet on Histopatology mice (Mus musculus) Hepar
}

\author{
Ervina Dewi1, Fadliyani 2, Ismiranda3
}

Program Studi Pendidikan Biologi

Fakultas Keguruan dan Ilmu Pendidikan Universitas Jabal Ghafur

Email : vinaunigha@gmail.com

\begin{abstract}
ABSTRAK
Penelitian ini bertujuan Mengetahui efek diet aterogenik terhadap gambaran histopatologis hati mencit (Mus musculus) jantan. Penelitian ini dilaksanakan di Laboratorium MIPA FKIP Universitas Jabal Ghafur dan Laboratorium Patologi Fakultas Kedokteran Hewan (FKH) Universitas Syiah Kuala pada bulan Maret sampai dengan Agustus 2017. Penelitian ini merupakan penelitian eksperimental laboratorium yang terdiri atas 2 perlakuan dan 4 ulangan. Perlakuan terdiri atas Pakan standar (Po) dan Pakan aterogenik (P1). Pembuatan sediaan histologis dengan menggunakan metode parafin. Parameter yang diamati adalah infiltrasi lemak, degenerasi lemak dan nekrosa sel hati mencit. Data yang diperoleh dianalis dengan uji T. Hasil penelitian menunjukkan diet aterogenik mampu merusak organ hati mencit perlakuan. Kerusakan yang ditimbulkan berupa meningkatnya rerata jumlah infiltrasi lemak, degenerasi lemak dan nekrosa sel hati mencit. Kesimpulan, diet aterogenik mampu meningkatkan infiltrasi lemak, degenerasi lemak dan nekrosa sel hati mencit (Mus musculus).

Kata Kunci : Diet Aterogenik, Degenerasi lemak, infiltrasi lemak, nekrosa, hepatosit.
\end{abstract}

\begin{abstract}
This research aimed to know the effct of aterogenic diet on histopatology mice hepar. The research was conducted from March to August 2017 at MIPA laboratory Jabal Ghafur University and Patology Laboratory FKH Syiah Kuala University. A experimental laboratory design was used with

2 treatments and 4 repetitions of each treatment. The treatments were standar weft $(\mathrm{P} 0)$ and aterogenic diet weft (P1). Paraffin method was apllied of microscopic structure observation. The parameters observed were lipid infiltration, lipid degeneration and necrosis of mice hepatocyte. A T test was tested to the data alteration of histopatology of mice hepatocyte. The result showed that diet aterogenic could significant to increase lipid infiltration, lipid degeneration and necrosis of mice hepatocyte. In conlusion, the diet aterogenic has ability to increase lipid infiltration, lipid degeneration and necrosis of mice hepatocyte.
\end{abstract}

Key word : diet aterogenic, lipid infiltration, lipid degeneration and necrosis, hepatocyte.

\section{PENDAHULUAN}

Perkembangan ilmu pengetahuan dan teknologi dewasa ini telah mampu merubah pola hidup masyarakat Indonesia, termasuk Nanggroe Aceh Darussalam. Umumnya, masyarakat sibuk dengan berbagai aktivitasnya, sepert kesibukan dalam bekerja atau lainnya. Hal ini memungkinkan masyarakat memiliki waktu yang sedikit untuk menerapkan gaya hidup sehat mulai dari pola makan yang tidak seimbang sampai kurangnya olah raga. Milias (2006) menjelaskan bahwa pola makan yang tidak seimbang meliputi konsumsi makanan yang tinggi lemak dan karbohidrat, konsumsi makanan rendah serat serta kebiasaan merokok dan minum alkohol. Selain itu juga disebabkan oleh stress emosional dan kelainan genetik (Hardiningsih dan Hidayat,

2006 ; Murray et al., 2009).

Penerapan gaya hidup tidak sehat menyebabkan munculnya berbagai macam penyakit. Salah satu penyakit yang timbul adalah hiperkolesterolemia.

Hiperkolessterolemia merupakan salah satu gangguan metabolisme yang ditandai dengan adanya kelainan metabolisme lipid dan ditandai dengan meningkatnya kadar kolesterol atau trigliserida dalam serum darah (Guyton dan Hall, 1997 ; Sudoyo et al., 2006). 
Hiperkolesterolemia mengindikasikan adanya akumulasi radikal bebas dalam tubuh. Radikal bebas ini dapat berasal dari lipid eksogen (Murray et al., 2009). Sofia (2005) menyatakan bahwa radikal bebas adalah spesi kimia yang memiliki pasangan elekton bebas di kulit terluar sehingga reaktif dan mampu breaksi dengan protein, lipid, karbohidrat atau DNA.

Hati merupakan salah satu organ pencernaan yang memetabolisme seluruh bahan makanan yang masuk ke tubuh, termasuk obat. Hati menjadi organ yang sering mengalami kerusakan yang disebabkan oleh berbagai faktor. Salah satu diantaranya adalah radikal bebas atau senyawa toksik. Toksik yang masuk ke dalam tubuh diangkut ke porta hati oleh vena porta. Hati memiliki enzim yang mampu memetabolisme senyawa toksik tersebut (Murray et al., 2009). Cara kerja hati dalam hal metabolisme seperti ini dapat mengakibatkan hati mudah rusak. Kerusakan hati dapat pula meliputi kerusakan struktur maupun gangguan fungsi (Guyton dan Hall,

1997).

Peningkatan radikal bebas menstimulasi proses peroksidasi lipid dan mengakibatkan stres oksidatif. Peningkatan radikal bebas juga menurunkan aktivitas enzim lipoprotein lipase (LPL) yang menyebabkan terjadinya akumulasi trigliserida (TG) dalam sel hati dan menimbulkan infiltrasi lemak, degenerasi lemak, bahkan menyebabkan sel hati mengalami kematian (nekrosa) sehingga memperparah kondisi tubuh. Hasil penelitian Ismiranda (2016) telah membuktikan bahwa pemberian pakan aterogenik mampu meningkatkan kadar kolesterol total serum darah mencit perlakuan. Selanjutnya pakan aterogenik juga mempengaruhi struktur mikroskopis organ hati. Hati mencit perlakuan mengalami infiltrasi lemak dan degenerasi lemak. Namun demikian, pengamatan secara terperinci tentang efek diet aterogenik terhadap gambaran histopatologi hati belum pernah dilakukan, mengingat perlemakan hati dapat mengakibatkan terganggunya fungsi hati bahkan menyebabkan nekrosa sel hati.

Berdasarkan latar belakang di atas, maka perlu dilakukan penelitian untuk mengetahui efek diet aterogenik secara terperinci terhadap gambaran histopatologi hati mencit (Mus musculus) yang berupa infiltrasi lemak, degenerasi lemak dan nekrosa. Dengan demikian diharapkan, hasil penelitian ini dapat menambah wawasan masyarakat akan bahaya yang dapat ditimbulkan akibat tingginya konsumsibahan pangan diet lemak terhadap organ hati.

\section{METODE PENELITIAN}

\section{Tempat dan Waktu Penelitian}

Penelitian ini dilaksanakan di duatempat yaitu :proses pemeliharaan dan pemberian perlakuan pada mencit perlakuan dilakukan di Laboratorium MIPA FKIP Universitas Jabal Ghafur dan pembuatan preparat organ hati mencit perlakuan dilaksanakan di Laboratorium Patologi Fakultas Kedokteran Hewan (FKH) Unsyiah. Penelitian ini berlangsung pada bulan Maret sampai dengan Agustus 2017.

\section{Alat dan Bahan Penelitian}

Alat yang digunakan adalah, timbangan digital analitik, oven, kandang mencit, dan botol minum mencit.

Bahan yang digunakan adalah mencit (Mus musculus) jantan umur 2 bulan dengan bobot 20 gr, akuades, etanol $96 \%, \mathrm{NaCl}$ fisiologis, pakan standar, Kuning telur, Lemak kambing dan Alkohol $70 \%$, Larutan Bouin.

\section{Jenis Penelitian dan Rencana Penelitian}

Penelitian ini merupakan penelitian eksperimental laboratorium yang terdiri dari 2 perlakuan dan masing-masing perlakuan terdiri dari 4 ekor mencit. Perlakuan terdiriatas P0 : kontrol negatif (hanya diberikan pakan standar + Aquades) dan P1 : kontrol positif (pemberian pakan aterogenik + Aquades).

\section{Prosedur Penelitian}

Penyiapan Hewan Coba

Penelitian ini menggunakan mencit (Mus musculus) jantan berumur 2 bulan dengan ratarata berat badan $20 \mathrm{~g}$. Mencit ini diaklimatisasi selama tujuh hari di kandang percobaan. Kandang mencit terbuat dari bak plastik dengan ukuran $27 \mathrm{~cm} \times 19,5 \mathrm{~cm} \times 9 \mathrm{~cm}$. Bagian atas kandang ditutup kawat jaring dan bagian bawah dialasi sekam dengan ketebalan $3 \mathrm{~cm}$. Mencit diberi pakan dan minuman secara ad libitum.

Pembuatan Pakan Aterogenik

Pembuatan pakan aterogenik mengacu pada Hernawati (2012).

\begin{tabular}{|l|c|}
\hline \multicolumn{1}{|c|}{ Bahan } & Kadar\% \\
\hline TepungJagung & 60 \\
\hline TepungIkan & 8 \\
\hline
\end{tabular}

Jurnal Sains Riset | Volume VIII Nomor I 


\begin{tabular}{|l|c|}
\hline BungkilKedelai & 20 \\
\hline KuningTelur & 3 \\
\hline MinyakKelapa & 6 \\
\hline Premiks & 1 \\
\hline Garam & 1 \\
\hline $\mathrm{CaCO}_{3}$ & 1 \\
\hline Total & $\mathbf{1 0 0}$ \\
\hline
\end{tabular}

\section{Pemberian Pakan Aterogenik}

Pakan aterogenik diberikan pada kelompok P1 (kontrol positif). Pakan aterogenik diberikan selama 30 hari secara ad libitum (Hernawati, 2012).

\section{Pengambilan Organ dan Pembuatan Sediaan Histologis}

Setelah hewan diterminasi dengan cara pembiusan menggunakan kloroform, dilakukan bedah bangkai, organ hati segera diambil dan selanjutnya dibuat sediaan histologis dengan metode parafin. Spesimen hati dimasukkan ke dalam larutan fiksatif bouin, kemudian dehidrasi dengan menggunakan alkohol seri $70 \%$ sampai dengan alkohol absolut, kliring dalam xilol, infiltrasi dan embedding dalam blok parafin

56 - 58 oC. Sediaan yang telah diembeddingdisayat dengan ketebalan 5 mikron menggunakan mikrotom putar. Setiap ulangan dibuat 4 sayatan dengan interval 10 sayatan dan diletakkan di atas kaca benda yang telah diberi larutan perekat. Untuk mengamati gambaran histologis hati, maka sediaan hati diwarnai dengan metode pewarnaan Hematoxylin Eosin (HE) yang mengacu pada Gridley (1960). Pengamatan histologis hati mengunakan mikroskop cahaya pada pembesaran 10 x 40 .

Parameter Yang Diamati

Parameter yang diamati pada penelitian ini adalah degenerasi lemak, infiltrasi lemak dan nekrosa sel hati mencit (Mus musculus) akibat pemberian pakan aterogenik.

\section{Analisis Data}

Data hasil penelitian berupa rerata degenerasi lemak, infiltrasi lemak dan nekrosa sel hati mencit (Mus musculus) akibat pemberian pakan aterogenik dianalisis dengan analisis dengan statistik uji-T .

\section{HASIL DAN PEMBAHASAN Gambaran Histopatologi Organ Hati}

Hasil penelitian terhadap gambaran histopatologi organ hati mencit perlakuan dapat dilihat pada

Gambar 1 di bawah ini.

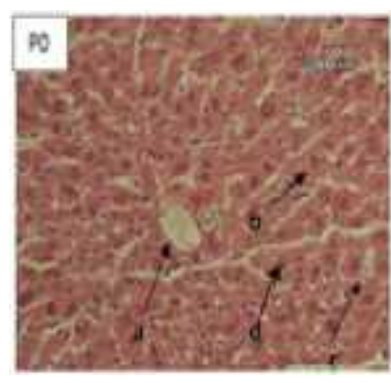

A

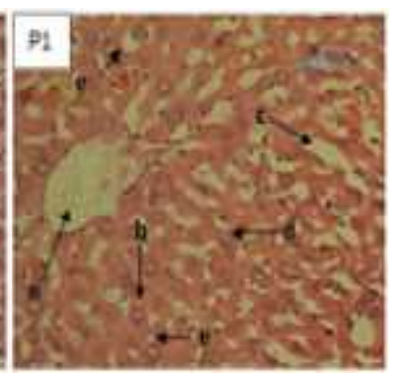

B
Gambar 1. Gambaran Histopatologis hati mencit perlakuan

Keterangan : a.Vena sentralis, b. Hepatosit, c. Sinusoid, d. Nukleus, e. Infiltrasi lemak, f. Degenerasi lemak

$\begin{array}{ll}\text { P0 } & \text { : Pakan Standar } \\ \text { P1 } & \text { : Pakan Aterogenik }\end{array}$

Gambar 1A memperlihatkan gambaran histologis hati memperlihatkan unsur utama hati yaitu hepatosit yang berbentuk polyhedral dan heksagonaldengan inti (nukleus) bulat. Diantara hepatosit terdapat sinusoid; merupakan pembuluh darah kapiler yang membawa darah menuju ke vena sentralis. Padagambar juga memperlihatkan vena sentralis dengan sangat jelas. Sel hati tersusun regular dengan perbandingan sitoplasma dan inti sel yang normal dan mengelilingi vena sentralis dengan sinusoid yang beraturan rapi.

Berbeda dengan Gambar 1A, Gambar 1B memperlihatkan bahwa pemberian pakan aterogenik selama 30 hari berturut-turut (P1) mampu merusak histologist hati mencit. Kerusakan tersebut ditandai dengan adanya perlemakan di hati. Perlemakan ini terdiri dari infiltrasi lemak (vakuola-vakuola lemak diluar sel hepatosit) yang membentuk ruang-ruang kosong akibat penimbunan lemak di luar sel hepatosit, dan degenerasi lemak (pembentukan vakuola- vakuola lemak yang memenuhi bagian sitoplasma hepatosit). Pada degenerasi lemak, pembentukan vakuola lemak memenuhi bagian sitoplasma sel hati sehingga mendesak inti sel hepatosit ke tepi. Sinusoid yang tampak tidak beraturan akibat sitoplasma sel hepatosit yang membesar. 
Hasil penelitian Sutejo dan Dewi (2012), juga memperlihatkan bahwa gambaran histopatologi hati yang telah diberikan pakan diet tinggi lemak memperlihatkan adanya fokusfokus degenerasi lemak yang ditandai dengan adanya mikrovesikular (vakuola lemak) dan peningkatan jumlah granule (round gl assappearance) pada sitoplasma, hilangnya sitoplasma (clear cell), sel membengkak (balloned cell), beberapa sel mengalami kerusakan membrane, susunan sel hati tidak teratur serta ukuran inti bervariasi dan struktur kromatin jelas, dan inti sel terdesak ke tepi.

Hasil penelitian Azman (2012) membuktikan bahwa pemberian pakan diet tinggi lemak menyebabkan hati mengalami steatosis yang ditandai dengan bertumpuknya vakuola lemak dalam sitoplasma.

Pada gambar juga ditemukan adanya sel hati yang mengalami nekrosa. Nekrosa merupakan suatu bentuk kematian sel yang meninggalkan respon inflamasi pada organ. Nekrosa ditandai dengan inti sel yang mengalami piknotis (pemadatan) dan sel hati yang sudah tidak lagi memiliki inti sel. Kondisi juga sejalan dengan penelitian Sutejo dan Dewi (2012) yaitu pemberian pakan tinggi lemak mampu menyebabkan nekrosa pada sel hati yang ditandai dengan adanya fragmen sel, sel tanpa pulasan inti, atau tidak tampaknya sel disertai reaksi radang; kromatin menggumpal menjadi untaian kasar; inti menjadi massa yang mengkerut, memadat, dan menjadi sangat basofilik (biru tua), yang disebut piknosis; inti piknotik pecah menjadi banyak partikelbasofilik kecil-kecil (karioreksis) atau mengalami lisis (kariolisis).

\section{Analisis Data Infiltrasi Lemak, Degenerasi Lemak dan Nekrosa}

Hasilpenelitianterhadapreratajumlahinfilt rasilemak,degenerasidannekrosaselhati mencitperlakuansetelahdiinduksipakanaterogen ikselama30haridapatdilihatpadaTabel1.

Tabel1.

RerataInfiltrasiLemak,degenerasilemakdannekr osa

\begin{tabular}{|c|c|c|c|c|}
\hline $\mathrm{N} \cdot$ & Perlalean & Innitrasl Lemak & Digcherast $1 . \mathrm{cmalt}$ & Yelinsa \\
\hline 1 & Piker siendie & $4.500^{1} \quad 4.968572$ & $1,792^{\circ} \quad 0,3758$ & $2,51: 4^{\prime} \mid 41.426: 7 ?$ \\
\hline i & 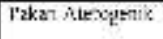 & $1+211^{3}-1302,34$ & mosit $=7, m 0 s k$ & $00,10 k^{2}=7.4831$ \\
\hline
\end{tabular}

Tabel 1 menunjukkan bahwa pemberian pakan aterogenik selama 30 hari berturut-turut mampu meningkatkan rerata infiltrasi lemak, degenerasi lemak dan nekrosa sel hati mencit perlakuan yang berbeda nyata dengan mencit yang hanya diberikan pakan standar $(\mathrm{P}<0,05)$. Hasil penelitian ini sejalan dengan penelitian Murwani et al . (2006) dan Ismiranda (2016) membuktikan bahwa pemberian pakan aterogenik mampu meningkatkan kadar kolesterol total serum darah mencit secara bermakna dibandingkan dengan kelompok pakan standar. Ismiranda (2016) juga menjelaskan bahwa pemberian pakan aterogenik mempengaruhi struktur mikroskopis hati mencit.

Myers (2003) menjelaskan, pakan tinggi kolesterol dari pakan yang diberikan menyebabkan peningkatan aktivitas lipogenesis, dan asam lemak bebas yang terbentuk juga semakin banyak. Selanjutnya terjadilah mobilisasi asam lemak bebas dari jaringan lemak menuju hati dan berikatan dengan gliserol membentuk trigliserida. Dengan demikian, semakin tinggi konsumsi lemak maka semakin tinggi pula sintesa trigliserida di hati dan semakin tinggi kadar trigliserida dalam darah menyebabkan degenerasi lemak dan infiltrasi lemak di hati.

Sumber lain menyebutkan bahwa tingginya asupan asam lemak dalam pakan aterogenik akan meningkatkan absorbsi asam lemak di usus sehingga asam lemak di darah juga tinggi. Adanya transpor asam lemak berlebihan yang diangkut dari luar kedalam hati mengakibatkan terjadinya penumpukan asam lemak dalam sel hati. Asam lemak jenuh yang disimpan di hati dalam jumlah besar dapat menimbulkan perlemakan hati.

Asam lemak tak jenuh dalam jumlah banyak pada membran mikrosomal sel hati juga meningkatkan kepekaan membran terhadap aktivitas radikal bebas yang bersifat autokatalitik. Aktivitas radikal bebas ini menghasilkan lipid peroksida yang menyebabkan kerusakan retikulum endoplasma kasar sehingga polisom akan terlepas (Wu and Cederbaum, 2003 dan Ong\& Goh, 2002). Sintesis protein terganggu, lemak yang ada dalam hati tidak bisa berikatan dengan protein membentuk lipoprotein untuk diangkut keluar hati.

Ditemukannya sel hati yang mengalami nekrosa dalam penelitian ini diduga disebabkan 
oleh pakan aterogenik yang bertindak sebagai radikal bebas. Sofia (2005) menyatakan bahwa radikal bebas adalah spesi kimia yang memiliki pasangan elekton bebas di kulit terluar sehingga reaktif dan mampu breaksi dengan protein, lipid, karbohidrat atau DNA. Peningkatan jumlah radikal bebas dalam tubuh mengakibatkan kemampuan pertahanan tubuh melalui sistem antioksidan berkurang mampu memicu stress oksidatif yangberujung pada berbagai penyakit. . Keadaan ini dipengaruhi oleh spesies oksigen reaktif (ROS). ROS merupakan molekul oksidan relatif tinggi, bersifat sangat tidak stabil sehingga cepat bereaksi dengan molekul lain. ROS terjadi baik secara endogen maupun eksogen, melalui aktifitas metabolik reguler, aktifitas gaya hidup dan diet (Trilling dan Jaber, 1996).

Peningkatan radikal bebas menstimulasi proses peroksidasi lipid dan mengakibatkan stres oksidatif. Peningkatan radikal bebas juga menurunkan aktivitas enzim lipoprotein lipase (LPL) yang menyebabkan terjadinya akumulasi trigliserida (TG) dalam sel hati. Akumulasi lemak dalam hati berlangsung terus menerus sehingga terjadi degenerasi lemak dan infiltrasi lemak. Selain hati, degenerasi lemak dan infiltrasi lemak juga dapat terjadi pada lapisan pembuluh darah (Mulyani,1997). Selain itu, akumulasi lemak juga mengakibatkan steatosis (Azman et al.,2012) dan nekrosa (Sutejo dan Dewi, 2012) yang memperparah kondisi tubuh dengan malfungsi hati (Guyton dan Hall, 1997 ; Scanlon dan Sander, 2006).

Mekanisme terjadinya kerusakan sel hati pada dasarnya sama dengan mekanisme kerusakan sel hati akibat diet pakan tinggi lemak, yaitu disebabkan oleh adanya radikalbebas. Diduga, sumber radikal bebas yang dapat menyebabkan nekrosa sel hati pada penelitian ini disebabkan oleh radikal bebas yang berasal dari pakan aterogenik yang jika bergabung dengan radikal bebas hasil metabolisme tubuh jumlahnya jauh lebih besar sehingga kerusakan sel hati yang ditimbulkan lebih berat. Muray et al. (2009) serta Sutejo dan Dewi (2012) menjelaskan bahwa pada dasarnya tubuh memiliki kemampuan membentuk senyawa radikal bebas (radikal bebas yang berasal dari metabolisme tubuh normal). Selanjutnya jika bergabung dengan radikal bebas yang berasal dari pakan aterogenik mampu memperparah kerusakan pada sel hati.

\section{KESIMPULAN}

Berdasarkan hasil penelitian dapat disimpulkan bahwa pemberian pakan diet aterogenik selama 30 hari berturut-turut mampu meningkatkan infiltrasi lemak, degenerasi lemak dan nekrosa secara bermakna dibandingkan pakan standar.

\section{DAFTAR PUSTAKA}

Azman, F. K., Zulkhairi, A., Azrina, A., Norhaizan, M. E., Rasadah, M. A., Zamree, M. S dan Khairul, K. A. K.

2012. Antiobesity Effect Of Tamarindus Indica L. Pulp Aqueous Extract In High-Fat Diet InducedObese Rats. The Japanes Society ofPharmacognosy and Springer.66:333-342.

Gridley, W. F., 1960. Manual of Special Staining Technic. 2nd Ed. London: Mc. Graw Hill Book Company Inc.

Guyton, A. C dan Hall, J. E. 1997. Fisiologi Kedokteran, Edisi 5. Terjemahan dan Text Book of Medical Physiology, oleh I. Setiawan, L. M. A. K. A. Tengadi, A. Santoso. EGC: Jakarta.

Hardinigsih R, Nurhidayat N. 2006.Pengaruh pemberian pakan hiperkolesterolemia terhadap bobot badan tikus putih wistar yang diberi bakteri asam laktat. Bogor: FMIPA UNS Surakarta.

Hernawati. 2012. Peran Berbagai Sumber Serat Pangan Pada Perbaikan Profil Lipid Darah Mencit Hiperkolesterolemia. Ringkasan Desertasi. Sekolah Pascasarjana Institut Pertanian Bogor.

Ismiranda. 2016 Analisis Potensi Antihiperkolesterol Ekstrak Etanol Buah Asam Jawa (Tamarindus indica L) terhadap Mencit(Mus musculus) yang Diinduksi Hiperkolesterol. Tesis. Program Pascasarjana Universitas Syiah Kuala, Banda Aceh.

Milias GA, Panagiotakos DB, Pitsavos C, Xenaki D, Panagopoulos G, Stefanadis C. 2006. Prevalence of Self-Reported Hypercholesterolemia and Its Relation of Dietary Habits, in Greek Adult; a National Nutrition \&Healthy Survey. Lipids In healthDisease 5 (5). 
Mulyani, G.T. 1997. Efek Diet Lemak Jenuh dan Lemak Tak Jenuh terhadap Pembentukan Lipid Peroksida dalam Darah Tikus Percobaan. Yogyakarta: Fakultas Kedokteran Hewan Universitas Gajah Mada.

Muray, R. K, D. K. Granner, P. A. Mayes.V. W.Rodwell, 2009. Biokimia Harper, edisi 27. Terjemahan dari Harper's Biochemistry oleh A. Hartono. Buku Kedokteran EGC, Jakarta.

Murwani. S., Ali M dan Muliartha K. 2006.Diet Aterogenik pada Tikus Putih (Rattus novergicus strain Wistar) sebagai Model Hewan Aterosklerosis. Jurnal Kedokteran Brawijaya, Vol. XXII, No. 1.

Myers, $2003 . \quad$ Interrelationship Betweenarbohydrate and Lipid Metabolism Biological Chemistry. California State University, Long Beach.

Ong, A. S. H. \& Goh, S. H. 2002. Palm oil: A healthful and cost-effective dietary component. Food and Nutrition Bull etin, vol. 23.

Scanlon. V.C.dan T. Sanders., 2006. BukuAjar Anatomi dan Fisiologi. Edisi3.
Terjemahan dari Essentials of Anatomy and Physiology. 3th edition. Oleh F.X Awal Prasetyo. Buku Kedokteran EGC, Jakarta.

Sudoyo, A. W., Setiyohadi, B., Alwi, A., Simadibrata, K. M., Setiadi, S. 2006. Buku Ajar Ilmu Penyakit Dalam Jilid III Edisi IV. Departemen Ilmu Penyakit Dalam Fakultas Kedokteran Universitas Indonesia: Jakarta

Sutejo, IR dan Dewi R,. 2012. Kerusakan sel hati dan peningkatkan Kolesterol Serum Mencit Akibat Pemberian Minyak Goreng Bekas Pakai. Jurnal IKESMA Volume 8 Nomor 1.

Trilling JS, Jaber R.1996. Selections from current literature: the role of free radicals and antioxidants in disease. Fam Pract : 13(3):322-6.

Wu, D., Cederbaum, A.I. 2003. Alcohol, Oxidative Stress, and Free Radical

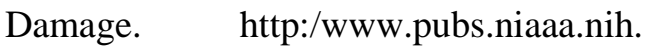
gov/arh27-4/277-284.htm. Diakses pada tanggal 18 Agustus 2015. 